\title{
Antifungal Activity of Some Plant Extracts against (Colletotrichum Musae) the Cause of Postharvest Banana Anthracnose
}

\author{
Setu Bazie ${ }^{1 *}$, Amare Ayalew² and Kebede Woldetsadik ${ }^{2}$ \\ ${ }^{1}$ University of Gondar, P.O. Box 196, Gondar, Ethiopia \\ ${ }^{2}$ School of Plant Sciences, Haramaya University, P.O. Box 138, Haramaya, Ethiopia
}

\begin{abstract}
The present study was conducted to determine the efficacy of extracts of some plant species against Colletotrichum musae. Methanolic extracts of 21 plant species were screened for their inhibitory effect against $C$. musae using paper disc method and spore germination assay. Among them, extract of Prosopis juliflora exhibited superior antifungal activity $(30.7 \mathrm{~mm})$, followed by Acacia albida $(19 \mathrm{~mm})$ as compared to nill in the control. On the other hand, carbendazim, which was used as a standard chemical check, demonstrated by far the highest inhibition zone of $51.7 \mathrm{~mm}$ diameter. Extracts from A. albida, Dovalis abyssinica and $P$. juliflora reduced conidial germination to $0.2,0.5$ and $0.3 \%$, respectively, which didn't vary statistically from $1.2 \%$ in Carbendazim. Six plant species, viz., A. albida, Azadirachta indica, Argemone mexicana, D. abyssinica, P. juliflora and Vernonia amygdalina, that showed high to moderate antifungal activity in the preliminary screening, were further tested for their thermal stability at $60^{\circ} \mathrm{C}$ and for the efficacy of their aqueous extracts against $C$. musae. Extracts of the tested plant species were found to be heat stable and aqueous extracts of $A$. albida showed the highest antifungal activity $(18 \mathrm{~mm})$, followed by $P$. juliflora $(12.3 \mathrm{~mm})$. Further studies need to be undertaken to isolate the active compounds from those extracts with fungicidal potential.
\end{abstract}

Keywords: Antifungal; Banana anthracnose; Colletotrichum musae; Plant extracts

\section{Introduction}

Anthracnose caused by the fungus Colletotrichum musae, is the most important postharvest disease of banana that can result in $30-40 \%$ losses of marketable fruit [1]. Recently, plant products have attracted high attention to search for some phytochemicals for their exploitation as antimicrobials; such plant products would be easily degradable less phyto-toxic and safe to human health [2]. However, no efforts have been made in Ethiopia to screen plants that have potential antimicrobial properties against C. musae. Several investigations have evaluated spices and medicinal plants with the aim of using them for plant disease management [3-5]. However, although many such plants have shown antimicrobial activity, their practical use for disease management has been limited because of the high price they fetch for other purposes. Thus, attention should be focused on plants with limited known economic values.

It has been suggested that combining plant extracts with nonchemical postharvest treatments, such as heat treatment, might control postharvest anthracnose diseases effectively [6]. However, the antifungal substances that are present in the plant extracts may be unstable at higher temperatures [7]. Accordingly, there is a need for investigating a heat stable plant extract that could be integrated with hot water treatments. This study was undertaken to determine the inhibitory effects of extracts of plants with limited economic value against C. musae.

\section{Materials and Methods}

\section{Experimental materials}

Fresh leaves of 21 plant species were collected from local sources. The identity of these plant species was confirmed at Haramaya University Herbarium where voucher specimens are deposited. The plants included Acacia albida, A. seyal, Argemone Mexicana, Azadirachta indica, Calotropis procera, Cassia occidentalis, Cynodon dactylon, Datura stramonium, Dovalis abyssinica, Lantana camara, Melia azedarach, Moringa olifera, Olea europaea, Petiveria alliacea, Plantago lanceolata, Prosopis juliflora, Ricinus communis, Schinus molle, Solanum incanum and Verbasacum sinaiticum.

\section{Isolation of the pathogen and inoculum preparation}

Banana fruits showing anthracnose disease symptoms were collected and used for isolation of Colletotrichum musae. Pure culture was maintained on PDA medium. Inoculum was prepared by dislodging the surface of 10 days old culture with sterile distilled water and adjusted to $105 \mathrm{ml}^{-1}$ using a hemacytometer.

\section{Extraction of plant samples}

Extraction was done using methanol and water. The methanolic extracts were used for preliminary screening of the plant specimens for their potency against the fungal pathogen, while aqueous extracts were used for further testing. Fifty gram of powdered samples of each of the plant specimens was extracted with $250 \mathrm{ml}$ solvent (methanol or water). The methanolic and aqueous extracts were filtered and reduced to dryness on rotary evaporator under vacuum at $40^{\circ} \mathrm{C}$ and $60^{\circ} \mathrm{C}$ water bath temperatures, respectively $[8,9]$. The extract of each plant was weighed, re-dissolved and then tested for antifungal activities.

\section{In vitro assay of plant extracts}

Paper disc method: The method as described by [9] was used.

*Corresponding author: Setu Bazie, University of Gondar, P.O. Box 196, Gondar Ethiopia, Tel: +251 58 1110174; Fax: +25158 1141240; E-mail: setubazie@gmail.com

Received: February 23, 2014; Accepted May 08, 2014; Published May 17, 2014

Citation: Bazie S, Ayalew A, Woldetsadik K (2014) Antifungal Activity of Some Plant Extracts against (Colletotrichum Musae) the Cause of Postharvest Banana Anthracnose. J Plant Pathol Microb 5: 226. doi:10.4172/2157-7471.1000226

Copyright: @ 2014 Bazie S, et al. This is an open-access article distributed under the terms of the Creative Commons Attribution License, which permits unrestricted use, distribution, and reproduction in any medium, provided the original author and source are credited. 
Briefly, sterile filter paper discs $(6 \mathrm{~mm}$ in diameter) were impregnated with $10 \mu \mathrm{l}$ plant extract (at a concentration of $100 \mu \mathrm{g} / \mu \mathrm{l}$ ). Five milliliter of a culture suspension of C. musae with a concentration of $1 \times 10^{6}$ conidia $\mathrm{ml}^{-1}$ was added to $250 \mathrm{ml}$ of PDA medium which had been previously cooled down to ca. $50^{\circ} \mathrm{C}$. The medium was then poured into Petriplate and allowed to solidify. The impregnated discs were dried and placed with forceps aseptically on the surface of the pre-inoculated PDA medium. Paper discs that were similarly handled but without plant extract served as untreated control and paper discs impregnated with commercial fungicide carbendazim (at the concentration of $2 \mu \mathrm{g} /$ $\mu \mathrm{l})$ served as a positive control. Four days of after incubation $\left(\right.$ at $\left.28^{\circ} \mathrm{C}\right)$, the diameter of inhibition zone around the test discs was measured and the degree of inhibition of fungal growth expressed on a 0-4 scale was recorded [9], where: $0=$ no inhibition zone visible, $1=$ inhibition zone barely distinct, fungal growth and sporulation only slightly inhibited, $2=$ inhibition zone well distinct fungal growth ca. $50 \%$ of the control, slight sporulation, $3=$ inhibition zone with sparse (ca. $25 \%$ of the control) fungal growth, $4=$ inhibition zone free of visible fungal growth.

Spore germination assay: In this assay, about $0.5 \mathrm{ml}$ of methanolic plant extract was pipetted into sterile test tubes and the solvent was allowed to evaporate at room temperature. About $4.5 \mathrm{ml}$ volume of potato dextrose broth was pipetted into the test tubes and mixed with extracts. At the same time an aliquot $(100 \mu \mathrm{l})$ of spore suspension (adjusted to $10^{6}$ conidia $\mathrm{ml}^{-1}$ ) was added into each tube. After $24 \mathrm{hr}$ of incubation at $28^{\circ} \mathrm{C}$ on a rotary shaker, a drop of the mixture from each tube were placed in a microscope slide and slides were fixed in lactophenol cotton blue and observed microscopically for spore germination. The same volume of methanol was added in place of plant extracts in the control samples and carbendazim at the concentration of $2.5 \mathrm{mg} / \mathrm{ml}$ served as a positive control. A conidium was considered as germinated if the length of the germ tube was at least half the length of the conidium. The number of germinated conidia was counted out of 100 randomly selected conidia in three replicate slides. Percentage spore germination was calculated according to the following formula:

pore Germination $(\%)=($ Germinated Spores $($ No. $) /($ Total Spores $($ No. $)) \times 100$

Thermal inactivation of plant extracts: Plant extracts showing potential antifungal activity in the preliminary evaluation were further tested for thermal stability. About $1 \mathrm{ml}$ of methanolic extracts in glass tubes were exposed to $60^{\circ} \mathrm{C}$ in a water bath for $10 \mathrm{~min}$ and cooled to room temperature. Afterwards, the paper disc method was employed to assess their effect on antifungal activity against C. musae as described under Section 2.4.1.

Statistical data analysis: Percentage data on spore germination inhibition was arcsine transformed before statistical analysis. The data were subjected to analysis of variance (ANOVA) using SAS software version 9.2 [10]. Means were separated using Duncan's Multiple Range test $(\mathrm{DMRT})$ at $\mathrm{P} \leq 0.05$.

\section{Results and Discussion}

\section{Antifungal activity of methanolic extracts}

Preliminary screening of 21 plant species was conducted for antifungal activity against Colletotrichum musae using mycelial inhibition test and spore germination assay.

Mycelial inhibition test: Out of the 21 plant species tested, Prosopis juliflora exhibited the highest antifungal activity with inhibition zone of $30.7 \mathrm{~mm}$ diameter against C. musae. The methanolic extract of A. albida showed the second best antifungal activity $(19 \mathrm{~mm})$, followed by $D$. abyssinica $(11.7 \mathrm{~mm})$ and A. mexicana $(11.0 \mathrm{~mm})$. Methanolic extract from $V$. amygdalina exhibited inhibitory activity of $9.7 \mathrm{~mm}$, while $A$. indica showed antifungal effect in the test with inhibition zone of 7.3 $\mathrm{mm}$. Regarding the degree of inhibition of fungal growth, expressed on a 0-4 scale, extracts of $A$. albida, A. mexicana, D. abyssinica, $P$. juliflora and $V$. amygdalina resulted in strong activity presenting zones of inhibition free of visible fungal growth. On the other hand, extracts of $A$. indica showed moderate activity against the test fungus.

Methanolic extracts of the remaining plant species and methanol, which served as negative control, produced no zones of inhibition. On the other hand, carbendazim, which was used as a standard chemical check, demonstrated by far the highest inhibition zone of $51.7 \mathrm{~mm}$ diameter.

The present study has demonstrated the antifungal potential of methanolic extract of $P$. juliflora that corresponded with the work done by [11] who reported methanolic extract of $P$. juliflora leaves to have excellent in vitro antifungal activity against soil mycoflora i.e. Fusarium oxysporum, Rhizoctonia solani, Alternaria alternata and Curvularia lunata. Extracts from A. albida showed potent activity and this result is in agreement with the previous finding of [12]. Similarly, antifungal effect of $A$. mexicana was previously reported by [13]. The antifungal activity of methanolic extract of $D$. abyssinica has also been reported [14].

Spore germination assay: Methanolic extract from A. albida, $D$. abyssinica and $P$. juliflora showed potent antifungal activity in reducing the spore germination to $0.2,0.5$ and $0.3 \%$, respectively. Carbendazim, used as a standard chemical check, markedly reduced spore germination percentage to $1.2 \%$ which is not significantly different $(\mathrm{P}>0.05)$ from the above most effective plant extracts (Tables 1 and 2). The extracts

\begin{tabular}{|c|c|c|}
\hline Plant species & $\begin{array}{c}\text { Zone of } \\
\text { inhibition }(\mathrm{mm})^{\mathrm{a}}\end{array}$ & Scale \\
\hline Carbendazim & $51.7^{\mathrm{a}}$ & 4 \\
\hline Prosopis juliflora & $30.7^{b}$ & 4 \\
\hline Acacia albida & $19^{c}$ & 4 \\
\hline Dovalis abyssinica & $11.7^{\mathrm{d}}$ & 4 \\
\hline Argemone mexicana & $11.0^{\mathrm{e}}$ & 4 \\
\hline Vernonia amygdalina & $9.7^{f}$ & 4 \\
\hline Azadirachta indica & $7.3^{9}$ & 3.5 \\
\hline Acacia seyal & $0.0^{\mathrm{h}}$ & 0 \\
\hline Calotropis procera & $0.0^{\mathrm{h}}$ & 0 \\
\hline Cassia occidentalis & $0.0^{\mathrm{h}}$ & 0 \\
\hline Cynodon dactylon & $0.0^{\mathrm{h}}$ & 0 \\
\hline Datura stramonium & $0.0^{\mathrm{h}}$ & 0 \\
\hline Lantana camara & $0.0^{\mathrm{h}}$ & 0 \\
\hline Melia azedarach & $0.0^{\mathrm{h}}$ & 0 \\
\hline Moringa olifera & $0.0^{\mathrm{h}}$ & 0 \\
\hline Olea europaea & $0.0^{\mathrm{h}}$ & 0 \\
\hline Petiveria alliacea & $0.0^{\mathrm{h}}$ & 0 \\
\hline Plantago lanceolata & $0.0^{\mathrm{h}}$ & 0 \\
\hline Ricinus communis & $0.0^{\mathrm{h}}$ & 0 \\
\hline Schinus molle & $0.0^{\mathrm{h}}$ & 0 \\
\hline Solanum incanum & $0.0^{\mathrm{h}}$ & 0 \\
\hline Verbasacum sinaiticum & $0.0^{\mathrm{h}}$ & 0 \\
\hline Control & $0.0^{\mathrm{h}}$ & 0 \\
\hline CV (\%) & 6.87 & \\
\hline
\end{tabular}

aValues are means of three replications and means within a column followed by the same letter are not significantly different $(P<0.05)$, DMRT

Table 1: In vitro antifungal activity of methanolic extracts of 21 plant species against Colletotrichum musae four days after incubation 


\begin{tabular}{|l|c|c|}
\hline Plant species & \multicolumn{2}{|c|}{ Conidial germination (\%) } \\
\hline Prosopis juliflora & 0.3 & $(2.0)^{\mathrm{k}}$ \\
\hline Acacia albida & 0.2 & $(2.2)^{\mathrm{k}}$ \\
\hline Dovyalis abyssinica & 0.5 & $(3.8)^{\mathrm{k}}$ \\
\hline Carbendazim & 1.2 & $(4.6)^{\mathrm{k}}$ \\
\hline Argemone mexicana & 5.6 & $(13.6)^{\mathrm{j}}$ \\
\hline Vernonia amygdalina & 8.7 & $(17.1)^{\mathrm{j}}$ \\
\hline Azadirachta indica & 13.0 & $(21.1)^{\mathrm{i}}$ \\
\hline Acacia seyal & 18.7 & $(25.6)^{\mathrm{h}}$ \\
\hline Plantago lanceolata & 19.7 & $(26.3)^{\mathrm{h}}$ \\
\hline Melia azedarach & 23.3 & $(28.9)^{\mathrm{gh}}$ \\
\hline Cynodon dactylon & 27.3 & $(31.5)^{\mathrm{g}}$ \\
\hline Petiveria alliacea & 34.1 & $(35.7)^{\mathrm{f}}$ \\
\hline Moringa olifera & 34.9 & $(36.2)^{\mathrm{f}}$ \\
\hline Ricinus communis & 78.5 & $(62.4)^{\mathrm{e}}$ \\
\hline Datura stramonium & 85.7 & $(67.8)^{\mathrm{d}}$ \\
\hline Verbasacum sinaiticum & 85.9 & $(68.0)^{\mathrm{d}}$ \\
\hline Cassia occidentalis & 91.0 & $(72.4)^{\mathrm{c}}$ \\
\hline Lantana camara & 91.8 & $(73.4)^{\mathrm{bc}}$ \\
\hline Solanum incanum & 93.3 & $(75.2)^{\mathrm{abc}}$ \\
\hline Olea europaea & 94.3 & $(76.3)^{\mathrm{abc}}$ \\
\hline Schinus molle & 95.0 & $(77.5)^{\mathrm{ab}}$ \\
\hline Untreated control & 95.4 & $(77.9)^{\mathrm{a}}$ \\
\hline Calotropis procera & 95.7 & $(78.1)^{\mathrm{a}}$ \\
\hline CV (\%) & & 5.70 \\
\hline
\end{tabular}

aPercentage of germinated spores $24 \mathrm{~h}$ after incubation (mean of three replications) bValues in the parenthesis are arcsine transformed

Means followed by the same letters within the column are not significantly different $(P<0.05)$, DMRT

Table 2: Effect of methanolic extracts of 21 plant species on conidial germination of Colletotrichum musae.

of $A$. mexicana and $V$. amygdalina reduced germination percentage to 5.6 and $8.7 \%$, respectively, and were statistically at par with each other. On the other hand, the extracts of C. procera, O. europaea, S. incanum and $S$. molle, were observed to be least effective in reducing conidial germination of $C$. musae and were at par with the conidial germination in the untreated control (95.4\%).

In the present study, spore germination was reduced to below $1 \%$ by methanolic extracts of A. albida, D. abyssinica and P. juliflora. Previous study conducted by [15] revealed that extracts of $P$. juliflora completely inhibited the germination of conidia of Phaeoisariopsis personata.

Thermal stability and antifungal activity of aqueous extracts: Extracts of A. albida, A. indica, A. mexicana, D. abyssinica, P. juliflora, and $V$. amygdalina that showed high activity against $C$. muase in the preliminary screening were further tested for their thermal stability and for the potency of their aqueous extracts. The results showed that there was no significant difference $(\mathrm{P}>0.05)$ between heated $\left(\right.$ at $\left.60^{\circ} \mathrm{C}\right)$ and unheated plant extracts in their efficacy against the test pathogen (Table 3). This indicates that temperature slightly above the hot water treatment (HWT) range had no effect on the antifungal activity of the plant extracts. The result of the study is supported by previous works $[16,17]$ that natural extract components are heat stable under moderate $\left(50-80^{\circ} \mathrm{C}\right)$ heat treatment. It is worthy to note that heat treatment slightly but insignificantly increased inhibition zone diameter (Table 3 ). In addition, the degree of inhibition of fungal growth was increased from 3.5 to 4 scales in the case of $A$. indica. This is in agreement with the earlier findings $[18,19]$ that heat treatments increased the activity of plant extracts. This may be due to an increase in the release of active compounds and free radicals [20].
Similarly, among the six plant species extracts tested, the highest zone of inhibition was exhibited by A. albida $(18 \mathrm{~mm})$ followed by $P$. juliflora $(12.3 \mathrm{~mm})$ (Table 4). Extracts of A. mexicana and D. abyssinica showed low antifungal activity with an inhibition zone of 7 and $6.7 \mathrm{~mm}$ diameter, respectively. On the other hand, aqueous extracts of $A$. indica and $V$. amygdalina showed no antifungal activity and the pathogen grew even on the paper discs. Distilled water, used as negative control, showed no zone of inhibition as expected. The fungi-toxic effect of aqueous extracts of $P$. juliflora against Aspergillus species [21] and Fusarium species [22] have been reported, which is in line with present result.

It is important to note that the activity of methanolic extracts of P. juliflora, A. indica, A. mexicana and D. abyssinica showed greater activity than their aqueous extracts (Tables 1 and 4). This is in harmony with the work of [11] that showed methanolic extracts have greater activity than the aqueous extract. This might be due to better solubility of the active components in organic solvents [23]. Furthermore, [24] indicated that such observations can be rationalized in terms of the polarity of the compounds being extracted by each solvent and, in addition to their intrinsic bioactivity, by their ability to dissolve or diffuse in the media.

\begin{tabular}{|c|c|c|c|}
\hline Temperature $\left({ }^{\circ} \mathrm{C}\right)$ & Plant species & $\begin{array}{c}\text { Zone of } \\
\text { inhibition }(\mathrm{mm})^{\mathrm{a}}\end{array}$ & Scale \\
\hline \multirow{6}{*}{$\begin{array}{l}\text { Room temperature } \\
\text { (ca. } 22 \text { ) }\end{array}$} & Prosopis juliflora & $29.7^{\mathrm{b}}$ & 4 \\
\hline & Acacia albida & $18.7^{c}$ & 4 \\
\hline & Dovyalis abyssinica & $10.7^{d}$ & 4 \\
\hline & Argemone mexicana & $9.3^{e}$ & 4 \\
\hline & Vernonia amygdalina & $8.7^{\mathrm{e}}$ & 4 \\
\hline & Azadirachta indica & $6.5^{f}$ & 3.5 \\
\hline \multirow[t]{6}{*}{60} & Prosopis juliflora & $30.7^{\mathrm{b}}$ & 4 \\
\hline & Acacia albida & $19.0^{c}$ & 4 \\
\hline & Dovyalis abyssinica & $11.0^{d}$ & 4 \\
\hline & Argemone mexicana & $9.7^{e}$ & 4 \\
\hline & Vernonia amygdalina & $9.0^{\mathrm{e}}$ & 4 \\
\hline & Azadirachta indica & $7.0^{f}$ & 4 \\
\hline \multirow[t]{2}{*}{ Control } & Carbendazim (ca. $22^{\circ} \mathrm{C}$ ) & $51.0^{\mathrm{a}}$ & 4 \\
\hline & Distilled water (ca. $22^{\circ} \mathrm{C}$ ) & $0^{g}$ & 0 \\
\hline CV (\%) & & 3.53 & \\
\hline
\end{tabular}

a Values are means of three replications.

Means within a column followed by the same letter are not statistically different $(\mathrm{P}<0.05)$, DMRT.

Table 3: Thermal inactivation of in vitro activity of six plant extracts against Colletotrichum musae four days after incubation.

\begin{tabular}{|l|c|c|}
\hline Plant species & $\begin{array}{c}\text { Zone of inhibition } \\
(\mathbf{m m})^{\mathrm{a}}\end{array}$ & Scale \\
\hline Carbendazim & $50.5^{\mathrm{a}}$ & 4 \\
\hline Acacia albida & $18^{\mathrm{b}}$ & 4 \\
\hline Prosopis juliflora & $12.3^{\mathrm{c}}$ & 4 \\
\hline Argemone mexicana & $7^{\mathrm{d}}$ & 3 \\
\hline Dovyalis abyssinica & $6.7^{\mathrm{d}}$ & 3 \\
\hline Azadirachta indica & $0^{\mathrm{e}}$ & 0 \\
\hline Vernonia amygdalina & $0^{\mathrm{e}}$ & 0 \\
\hline Untreated control & $0^{\mathrm{e}}$ & 0 \\
\hline CV (\%) & 4.14 & \\
\hline
\end{tabular}

avalues are means of three replications.

Means within a column followed by the same letter are not significantly different $(P<0.05)$, DMRT

Table 4: In vitro antifungal activity of aqueous extracts of six plant species against Colletotrichum musae four days after incubation. 
Citation: Bazie S, Ayalew A, Woldetsadik K (2014) Antifungal Activity of Some Plant Extracts against (Colletotrichum Musae) the Cause of Postharvest Banana Anthracnose. J Plant Pathol Microb 5: 226. doi:10.4172/2157-7471.1000226

\section{Conclusions}

In the preliminary screening of methanolic extracts of 21 different plant species against Colletotrichum musae, Acacia albida and Prosopis juliflora were the most effective in inhibiting mycelial growth of the test fungus (19.0 and $30.7 \mathrm{~mm}$, respectively), while Argemone mexicana, Dovalis abyssinica and Vernonia amygdalina showed good antifungal activity (11.0, 11.7 and $9.7 \mathrm{~mm}$, respectively). Spore germination was affected by some of the plant extracts but complete inhibition was not achieved by any of them. In the second stage screening, the results of heat inactivation test showed that all plant extracts tested were thermally stable at $60^{\circ} \mathrm{C}$. Aqueous extracts of A. albida and P. juliflora showed the highest activity in the second stage screening $(18.0$ and $12.3 \mathrm{~mm}$, respectively). This is the first report of $A$. albida and P. juliflora activity against $C$. musae. Further studies are warranted on isolating the active components found in the plant extracts for chemical characterization and possible use for postharvest management of C. musae.

\section{Acknowledgments}

The authors wish to thank Educational Sector Development Plan (ESDP) Italian Project for the financial support and Haramaya University for the material support.

\section{References}

1. Ranasinghe LS, Jayawardena B, Abeywickrama K (2003) Use of waste generated from cinnamon bark oil extraction as a postharvest treatment of Embul banana. J Food Agric Environ 1: 340-344.

2. Llondu EM (2011) Evaluation of some aqueous plant extracts used in the control of pawpaw fruit (Carica papaya L) rot. fungi J Appl Biosci 37: 2419-2424.

3. Amadioha AC (2003) Evaluation of some Plant Leaf Extracts against Colletotrichum lindemuthianum in Cowpea. Acta Phytopathol Entomol Hung 38 (3-4): 259-265

4. Obagwu J, Korsten L (2003) Control of citrus green and blue molds with garlic extracts Eur J plant pathol 109: 221-225.

5. Abd-El-Khair H, Haggag WM (2007) Application of some Egyptian medicinal plant extracts against potato late and early blights. J Agric Biol Sci 3: 166-175.

6. Bautista-Baños S, Barrera-Necha LL, Bravo-Luna L, Bermudez-Torres K (2002) Antifungal activity of leaf and stem extracts from various plant species on the incidence of Colletotrichum gloeosporioides of papaya and mango fruit after storage. Mexican J Phytopathol 20: 8-12.

7. Sanzani S, Nigro MF, Mari M, Ippolito A (2009) Innovations in the Control of Postharvest Diseases of Fresh Fruit and Vegetables. Arab J Plant Prot 27: 240244

8. Ramı́rez-Tortosa MC, Mesa MD, Aguilera MC, Quiles JL, Baro L, et al (1999) Oral administration of a turmeric extract inhibits LDL oxidation and has hypocholesterolemic effects in rabbits with experimental atherosclerosis. Atheroscler 147: 371-378.

9. Amare A (2002) Mycoflora and mycotoxins of major cereal grains and antifunga effects of selected medicinal plants from Ethiopia Doctorial Dissertation, Cuvillier Verlag Gottingen, Germany: 118.

10. SAS (Statistical Analysis System) Institute (2002) SAS/STAT® 92 user's guide for personal computers, Version 92 edition SAS Institute Inc, Cary, NC, USA

11. Lakshmi BS, Naidu KC, Murthy YLN, Bobbarala V, Pandit N (2010) Bio-efficacy of some medicinal plants against pathogens of cereal crops and phytochemical examination of Prosopis juliflora (Sw) Dc J Pharm Res 3 (2), 356-360.

12. Kubmarawa D, Ajoku GA, Enwerem NM, Okorie DA (2007) Preliminary phytochemical and antimicrobial screening of 50 medicinal plants from Nigeria. Afr J Biotechnol 6: 1690-1696.
13. Singh S, Singh AJ, Jaiswal TD, Singh VP, Singh VB et al. (2010) Antifungal activity of the mixture of quaternary alkaloids isolated from Argemone mexicana against some phytopathogenic fungi Arch Phytopathol Plant Prot 43: 769-774.

14. Geyid A, Abebe D, Debella A, Makonnen Z, Aberra F, et al. (2005) Screening of some medicinal plants of Ethiopia for their anti-microbial properties and chemical profiles. J Ethnopharmacol 97: 421-427.

15. Kishore GK, Pande S (2005) Integrated management of late leaf spot and rus diseases of groundnut (Arachis hypogaea $L$ ) with Prosopis juliflora leaf extract and Chlorothalonil. Int J Pest Manag 51 (4), 325-332.

16. Adegoke SA, Opata OM, Olajide JE (2010) Antimicrobial activity of the aqueous, methanol and chloroform leaf extracts of Cissus multistriata. Afr $J$ Biotechnol 9: 1168-1172.

17. Jariyawaranugoon U, Akesowan A (2010) Effect of thyme and lemongrass extracts on quality characteristics of Thai coconut cream dip during storage. $J$ Appl Sci Res 6: 1596-1602

18. Doughari JH, Manzara S (2008) In vitro antibacterial activity of crude leaf extracts of Mangifera indica Linn. Afr J Microbiol Res 2: 67-72.

19. El-Mahmood AM, Doughari JH, Kiman HS (2010) In vitro antimicrobial activity of crude leaf and stem bark extracts of Gmelina arborea (Roxb) against some pathogenic species of Enterobacteriaceae Afr J Pharm Pharmacol 4: 355-361.

20. Majumder AM, Upadhyay AS, Pradhan AM (1998) Effect of Azadirachta indica leaf extract on Carbon tetrachloride induced hepatic, damage in albino rats. Ind J Pharm Sci 60: 363-367

21. Satish S, Mohana DC, Ranhavendra MP, Raveesha KA (2007) Antifungal activity of some plant extracts against important seedborne pathogens of Aspergillus sp. J Agric Technol 3: 109-119.

22. Satish S, Raghavendra MP, Raveesha KA (2009) Antifungal potentiality of some plant extracts against Fusarium sp. Arch Phytopathol Plant Prot 42: 618-625.

23. Ekpo MA, Etim PC (2009) Antimicrobial activity of ethanolic and aqueous extracts of Sida acuta on microorganisms from skin infections. J Med Plants Res 3: 621-624.

24. Parekh J, Jadeja D, Chanda S (2005) Efficacy of aqueous and methano extracts of some medicinal plants for potential antibacterial activity. Turk J Biol 29: 203-210. 